\title{
Comparative Evaluation of Four Honeybee Races According To Pollen Storage and Worker Brood Rearing Activities Under Natural Conditions
}

\author{
Waleed Khaled Muhammad Elaidy ${ }^{1 *}$, Abd El-Monem Abdo Tolba ${ }^{2}$ \\ ${ }^{I}$ Department of Zoology, Faculty of Science, Mansoura University, Dakahlia province, Egypt \\ ${ }^{2}$ Department of Beekeeping Research, Plant Protection Research Institute, Dokki, Giza province, Egypt
}

\begin{abstract}
This comparative study was carried out between Carniolan, Carniolan hybrid, Italian and Italian hybrid races of Apis mellifera to evaluate their workers brood rearing and pollen storage activities during a whole year under the natural temperature and relative humidity conditions. The largest amounts of stored pollen and workers brood were recorded in spring and the lowest were in winter for all races. It was observed two peaks of stored pollen amounts in May (clover season) and August (maize season), while, the lowest amounts were recorded in December. There were significant positive correlations between the temperature and amounts of stored pollen in Italian hybrid and Carniolan races, while, Italian and Italian hybrid races significantly and negatively correlated with relative humidity. There was two peaks in workers brood rearing activity in March and November. It had a significant negative correlation with relative humidity, whereas, there was no correlation with temperature. Perhaps, it is due to the internal and external factors affect all activities of honey bees. The Italian race was the most efficient in pollen storage and workers brood rearing activities, as well as the Italian and Carniolan races surpassed their hybrids.
\end{abstract}

Keywords: Apis mellifera, races, pollen, brood

\section{Introduction}

Managed honeybees are not only important for honey but also vital as pollinators of wild plants and agricultural and horticultural crops worldwide. Honeybees are cheap, versatile and convenient among the most important productive livestock [1]. Apiculture is an economic activity, which is firmly established in Egypt and directed almost completely to the production of high quality honey. Nowadays, consumers are more and more interested in other honeybee products such as pollen, royal jelly, wax and propolis. Honeybees collect pollen to use it as food for all the developmental stages in the hive [2]. Pollen grains are the male reproductive cells of flowers and are fine powder-like material [3] whose composition vary due to their botanical origin [4]. Pollens contain carbohydrates, amino acids, proteins, lipids, vitamins, minerals, phenolic compounds, flavonoids, phytosterols and are also rich in phytochemicals $[\mathbf{5}, \mathbf{6}]$. Phytochemicals, such as phenolic compounds have antimicrobial [3] and antioxidant [7] activities. This work deals with mixed pollen collected and stored inside honeybee colonies because it would be economically impossible for beekeepers to separate pollens into families before selling it as cited by [8].

Colony conditions have a great economic impact worldwide. For the nonreproducing worker caste of social insects, colony growth and reproduction are the principal sources of fitness [9]. In general, a larger adult population results in increased probabilities for its colony to reproduce and for swarms to survive [10]. Thus, the mechanism for colony growth is the increase in the workers brood rearing activity that plays an important role in the regular development of the colony. The growing larvae are fed with protein-rich royal jelly, which the nurse bees secrete from their hypopharyngeal and mandibular glands [11]. The productivity of honey bee colonies throughout the year is particularly influenced by egg laying capacity, colony population and supply of both pollen and nectar $[12,13]$. On the other hand, among the abiotic factors, temperature has been found to be the most important that governs honeybee activities, especially queen's egg laying and brood production [14]. Young honeybee workers exhibit a weak hygropreference for approximately $75 \%$ relative humidity in the absence of brood and when brood is present, this preference further weakened [15].

Honey bees, slightly differ in their shapes and show morphological uniformity, but they greatly and considerably differ in their environment and geographical distribution. The European honey bee, Apis mellifera, is the most common and commercially important managed bee in the world. As a highly adaptable species, it has a native range that stretched from the southern parts of Scandinavia to Central Asia and throughout Africa. Within Apis mellifera, more than two dozen subspecies are recognized that correspond to the great variety of climatic zones to which the species is endemic [16]. The Egyptian honey bee race, Apis mellifera lamarckii, is less common, virulent, has small colony population and produces low amount of honey [17]. In Egypt, beekeeping is concerned with two common races; the carniolan race, Apis mellifera carnica, and the Italian race, 
A. $m$. ligustica. The Italian honey bees have a very compact brood nest and as the season progressed, they gave a good account. The brood development starts in early spring which produces a large populations until fall. The brood rearing of Carniolan race has been found directly related to the availability of pollen and the brood nest is compact and uniform [18]. Pollen is packed in rainbow layers around the brood, surrounded by honey extending to the edges of the frames [19]. Several studies focused on the difference between Apis mellifera races and their activities under environmental conditions $[20,21,22]$. The production of bee pollen may help in the economic profits increase but nationally, it is scarce and does not satisfy the consumer demand. The current paper aims to evaluate four honey bee races namely; Apis mellifera carnica (Carniolan), Carniolan hybrid (F1), Apis mellifera ligustica (Italian race) and Italian hybrid (F1) races for brood rearing and pollen storage activities under the natural conditions of temperature and relative humidity.

\subsection{Apiary and experimental design}

\section{Materials and methods}

This study was carried out in a private outdoor apiary at Monshaat El-Gharby [30 ${ }^{\circ} 566^{\prime} 50.1$ "N 31 36 '52.5"E], Temai-El-Amdeid district, Dakahlia province, Egypt and conducted for a whole year from March 2010 to February 2011. The Italian mated queens were purchased from Beekeeping Research Department, Plant Protection Research Institute, Dokki, Giza province, Egypt. The Carniolan mated queens were purchased from Manzala Beekeeping Research Unit, Plant Protection Research Institute, Dakahlia province, Egypt. Their hybrids were produced in the apiary to obtain Italian, Italian hybrid (F1), Carniolan and Carniolan hybrid (F1) races. For evaluation of the brood rearing and pollen storage activities of these four races, sixteen typical Langstroth hives were randomly chosen and divided into 4 groups with 4 colonies for each race as replicates. All colonies were nearly similar in strength with 8 combs covered with bees and containing adequate amount of brood, honey and stored pollen. Each colony was headed with a newly-mated and active egg-laying queen from the same race.

\subsection{Pollen source plants and climatic factors}

A general survey was carried out for identification of the common pollen source plants in the apiary region during the study. The survey expanded to cover a circle with a diameter of about $10 \mathrm{~km}$ and the plant flowering periods were determined. The study included the effect of temperature and relative humidity on the brood rearing and pollen grains storage activities. The values of temperature and relative humidity were continually recorded all over the year of study. The recorded values were obtained from the Bulletins of Meteorology Station, Administration of Agricultural Extension, Directorate of Agriculture, Mansoura, Dakahlia province.

\subsection{Estimation of sealed worker brood and stored pollen amounts}

The size of sealed worker brood is expressed as an area, which is measured as square inches. It was used $1 \times 1$ inch wire grid on a typical Langstroth frame directly placed over the brood comb to estimate the total square inches of brood for each side of the comb. The frame was 19 inches in length and 7 inches in width and was divided into a total of 133 square inches, each of them equals 25 worker brood cells. The total area of sealed worker brood cells in all the colony combs was calculated. The values were recorded at intervals of 12 days according to [23]. The same method was used to count the number of square inches of stored pollen in the four race colonies [24]. It was estimated the mean weight of pollen $(\mathrm{g}) / \mathrm{cell} / \mathrm{race}$, which was used in the calculation of stored pollen amount for each colony according to the following equation (1):

$$
\text { Pollen amount }(\mathrm{g})=\text { Stored pollen area }(\mathrm{sq} . \text { in }) \times 25(\text { cells }) \times \text { Mean wt. of pollen }(\mathrm{g})
$$

\subsection{Statistical analysis}

The obtained data were checked for normality and homogeneity of variance with Klomogrov-Smirnov and Levene tests, respectively. Parametric data were analyzed with Two-Way ANOVA followed by LSD test for post-comparison. Non-parametric data were analyzed with Kruskal-Wallis test followed by Mann-Whitney $(U)$ test. For correlation coefficient, Pearson and Kendall tau-b tests were used in case of parametric and nonparametric data, respectively. All data were statistically manipulated using SPSS Statistics program 17.0@ 1993-2007.

\subsection{Sources of pollen and climatic factors}

\section{Results}

The survey was carried out during the experiment for the pollen source plants. It was found major eleven plant sources of pollen according to the experimental region include ornamental plants and crops. These botanical sources were responsible for the wide variation in pollen properties whether they are physical or chemical. The variety of the trees and shrubs are shown with their duration, families and flowering periods 
(Table 1). The average values of the recorded temperatures ranged from 14.67 to $28.22^{\circ} \mathrm{C}$ and the averages of the recorded relative humidity values ranged from 59.21 to $71.48 \%$ allover the year of study (Figs. $1 \& 6$ ).

Table 1. Plant sources of pollen and their flowering periods at the experimental region in Monshaat El-Gharby, Temai-El-Amdeid, Dakahlia Province (2010/2011).

\begin{tabular}{|c|l|l|l|c|c|}
\hline No. & \multicolumn{1}{|c|}{ English name } & \multicolumn{1}{|c|}{ Scientific name } & Duration & Family & Flowering period \\
\hline 1- & Camphor & Eucalyptus rostrate Schleeht. & Perennial & Myrtaceae & Mar - Sep \\
\hline 2- & Casuarinas & Casuarina equisetifolia L. & Perennial & Casuarinaceae & Mar - Apr \\
\hline 3- & Willow & Salix babylonica L. & Perennial & Salicaceae & Feb - Mar \\
\hline 4- & Willow & Salix subserrata Willd. & Perennial & Salicaceae & Feb - May \\
\hline 5- & Green gem & Ficus nitida Thunb. & Perennial & Moraceae & Mar - Apr \\
\hline 6- & Royal poinciana & Delonix regia Raf. & Perennial & Fabaceae & Feb - Mar \\
\hline 7- & Acacia & Acacia arabica (Lam.) Willd. & Perennial & Fabaceae & Mar - Apr \\
\hline 8- & Sweet orange & Citrus sinensis L. & Perennial & Rutaceae & Apr - May \\
\hline 9- & Date palm & Phoenix dactylifera L. & Perennial & Arecaceae & Apr - May \\
\hline 10- & Clover & Trifolium alexandrinum L. & Annual & Fabaceae & Aug \\
\hline 11- & Maize & Zea mays L. & Annual & Gramineae & \\
\hline
\end{tabular}

\subsection{Pollen storage activity}

The pollen amounts stored by the evaluated four races increased gradually during the nectar flow season in March and April. The first peak was recorded in May and the averages were 108, 97, 91, $73 \mathrm{~g} /$ colony, representing 19.6, 19.5, 16.6 and $13.4 \%$ of the total amounts stored during the year by Italian, Carniolan hybrid, Italian hybrid and Carniolan colonies, respectively. Then, the pollen amounts decreased in June and gradually increased again during July and August. In August, it was observed the second peak with averages of 68, 64, 61 and $51 \mathrm{~g}$ /colony, representing 12.52, 12.87, 11.13 and $9.26 \%$ of the total amounts stored by Carniolan, Carniolan hybrid, Italian hybrid and Italian colonies during a whole year, respectively. Whereas, in December, it was recorded the lowest stored pollen amounts in Carniolan, Italian hybrid, Carniolan hybrid and Italian colonies with averages of 31, 28, 25 and $24 \mathrm{~g}$ /colony, representing 5.71, 5.11, 5.03 and 4.36\%, respectively (Fig. 1).

In spring, there was a significant increase in the pollen amounts stored by Italian colonies in comparison with Carniolan and Carniolan hybrid ones. There was insignificant difference between Italian and Italian hybrid races and between Carniolan and Carniolan hybrid ones. The average values were 79, 72, 57, and $53 \mathrm{~g} /$ colony stored by Italian, Italian hybrid, Carniolan hybrid and Carniolan colonies, respectively. In summer, the amounts were 56, 52, 45 and $40 \mathrm{~g}$ /colony stored by Carniolan, Italian hybrid, Italian and Carniolan hybrid colonies, respectively. In autumn, the stored pollen amounts were 37, 34, 30 and $30 \mathrm{~g} /$ colony stored by Carniolan, Carniolan hybrid, Italian and Italian hybrid colonies, respectively. Meanwhile, the lowest amounts of stored pollen were recorded in winter with averages of 35, 34, 30 and $29 \mathrm{~g} /$ colony stored by Carniolan, Carniolan hybrid, Italian and Italian hybrid colonies, respectively (Fig. 2).

The highest percentage of pollen amount was recorded by the Italian race in spring as $42.83 \%$ of the yearly total amount. Then, it decreased in summer, autumn and winter as $24.32,16.52$ and $16.33 \%$, respectively. The same was observed for the Italian hybrid race, which stored 39.23, 28.47, 16.42 and $15.88 \%$ of the total yearly pollen amount in spring, summer, autumn and winter, respectively. Also, the Carniolan hybrid race stored $34.62,24.14,20.52$ and $20.72 \%$ in the same seasons, respectively. Meanwhile, Carniolan race stored the highest percentage of pollen amount in summer as 30.945 followed by $29.47,20.26$ and $19.34 \%$ in spring, autumn and winter, respectively (Fig. 3). Italian and Italian hybrid races stored the highest amounts of pollen with total averages of 45.92 and $45.67 \mathrm{~g} /$ colony/year, respectively. Meanwhile, Carniolan and Carniolan hybrid races stored 45.25 and $41.42 \mathrm{~g} /$ colony/year, respectively.

The Italian hybrid and Carniolan colonies were more sensitive to temperature and the Italian and Italian hybrid colonies were more sensitive to relative humidity. There was a significant positive correlation between temperature and stored pollen amount in Italian hybrid and Carniolan colonies. Correlation coefficients were 0.377 and 0.583 and determination coefficients were 14.20 and $34.02 \%$, respectively (Fig. 4). Meanwhile, there was a significant negative correlation between relative humidity and stored pollen amount in Italian and Italian hybrid colonies. Correlation coefficients were -0.385 and -0.343 and determination coefficients were 14.81 and $11.77 \%$, respectively (Fig. 5). 


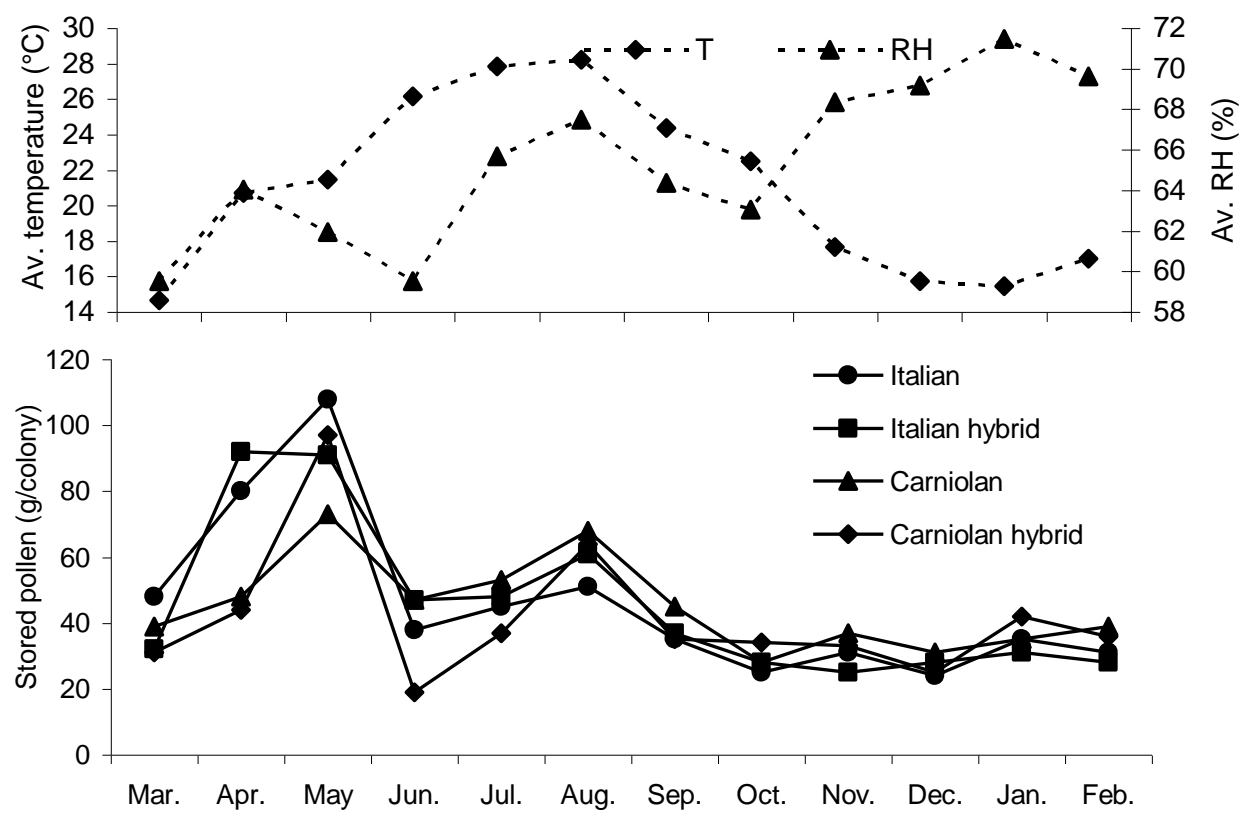

Fig. 1. Monthly average amounts of stored pollen in honey bee race colonies under natural temperatures and relative humidity conditions during a whole year.

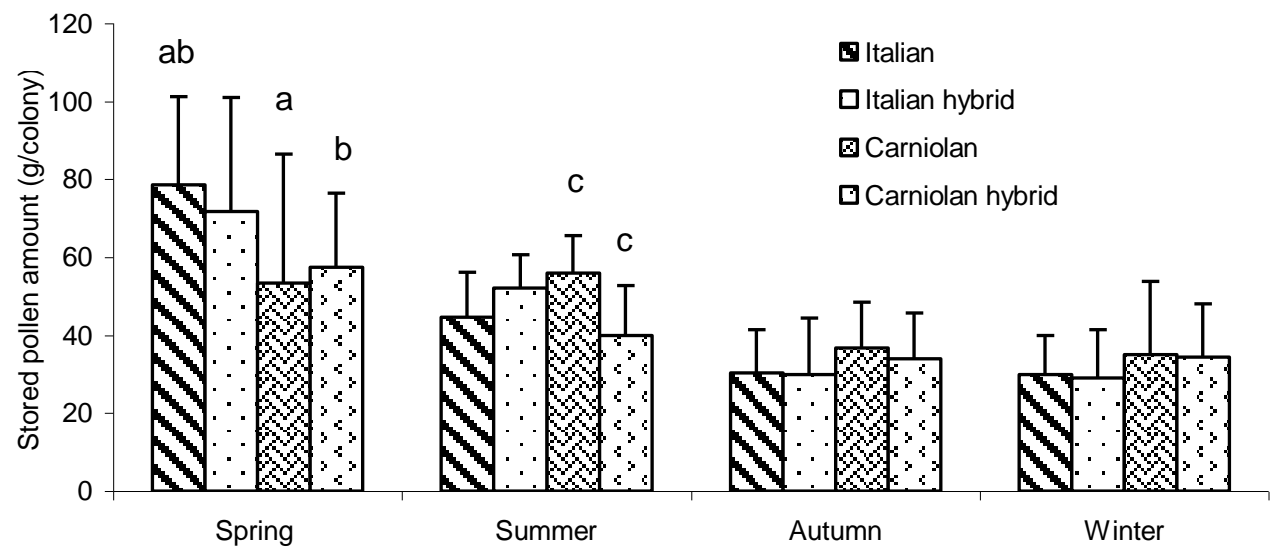

Fig. 2. Seasonal average amounts of stored pollen in honey bee race colonies under natural temperatures and relative humidity conditions during a whole year. The bars representing SD and the same letter means a significant difference.

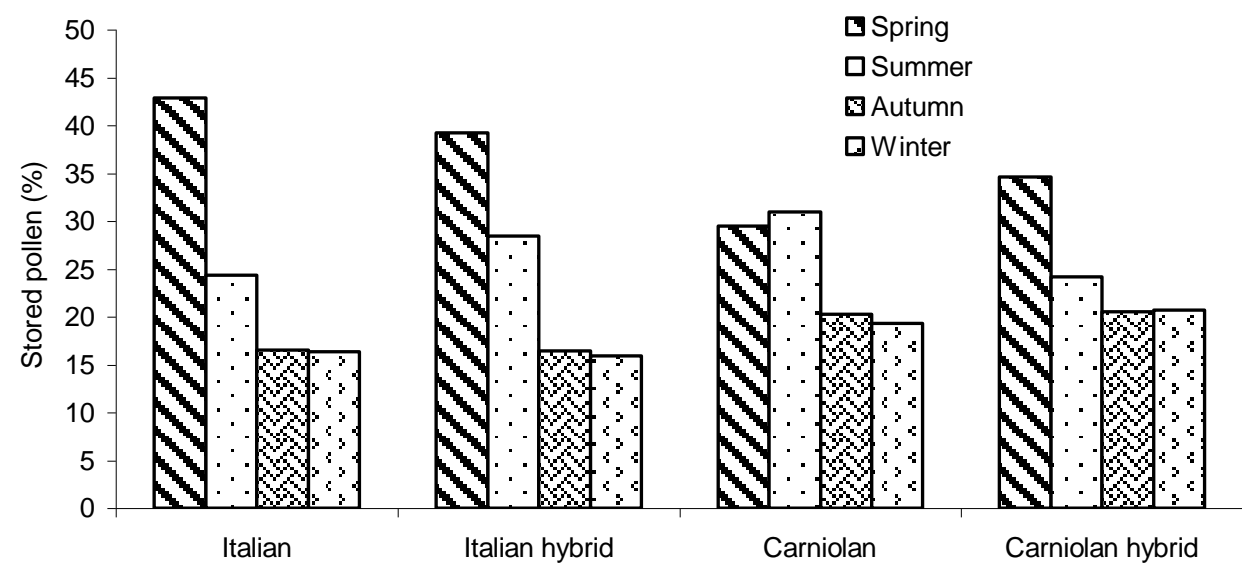

Fig. 3. Percentage of stored pollen in honey bee race colonies under natural temperature and relative humidity conditions during a whole year. 
Italian hybrid

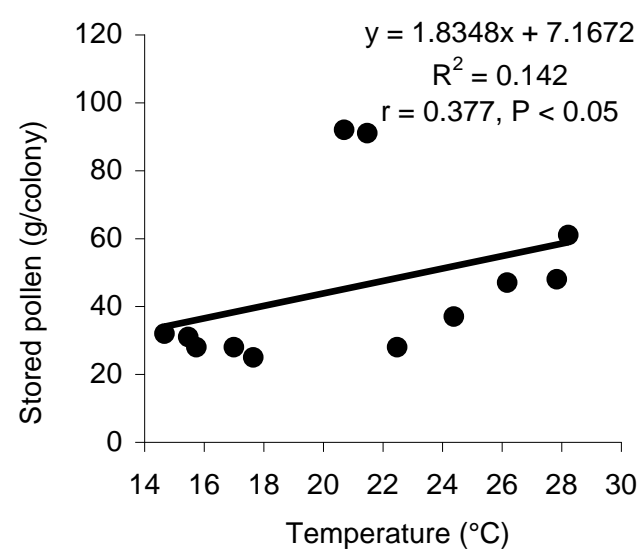

Carniolan

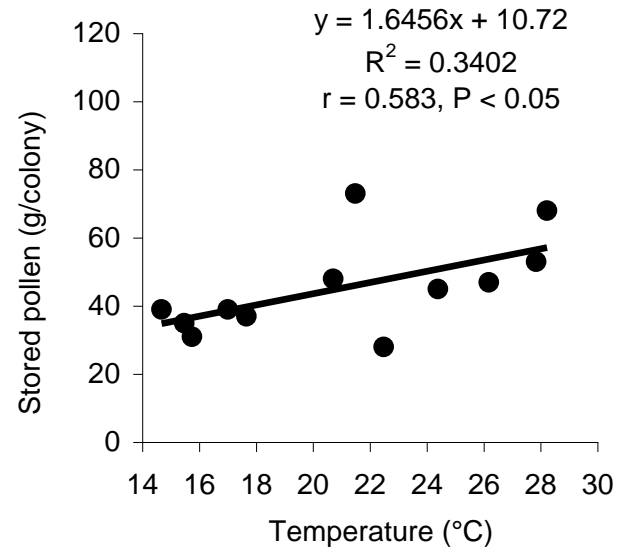

Fig. 4. Regression analysis and correlation between temperature and stored pollen in honey bee race colonies during a whole year. $\mathrm{R}^{2} \times 100=$ determination coefficient and $\mathrm{r}=$ correlation coefficient.

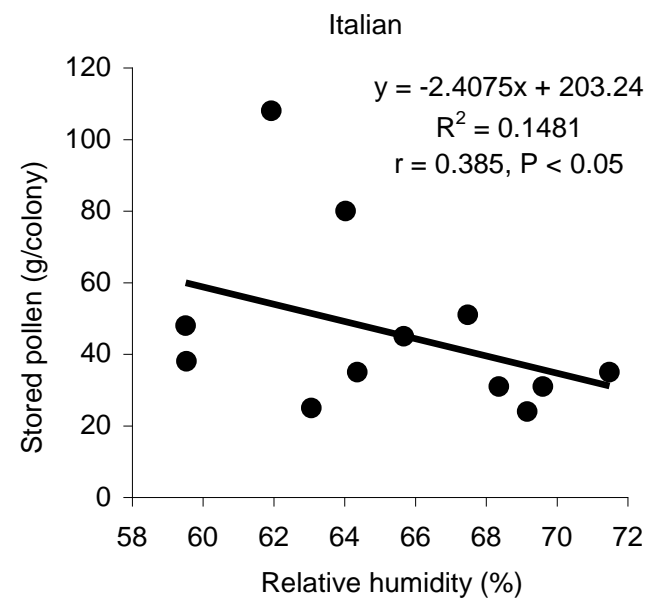

Fig. 5. Regression analysis and correlation between relative humidity and stored pollen in honey bee race colonies during a whole year. $\mathrm{R}^{2} \times 100=$ determination coefficient and $\mathrm{r}=$ correlation coefficient.

\subsection{Workers brood rearing activity}

The workers brood rearing activity of the four honey bee races had two peaks in March and November. In March, the averages of sealed worker brood areas were 622, 574, 555 and 437 sq. in/colony representing, $13.72,14.59,15.09$ and $12.92 \%$ of the total amount of workers brood reared during the year by Italian, Carniolan, Italian hybrid and Carniolan hybrid colonies, respectively. Then, the worker brood amounts gradually decreased until October with slight increase in August for the four tested races. The second peak was recorded in November with averages of 576, 514, 456 and 448 sq. in/colony representing, 12.70, 13.06, 12.39 and $13.24 \%$ in Italian, Carniolan, Italian hybrid and Carniolan hybrid colonies, respectively. The lowest averages were recorded in February with 222, 128, 119 and 110 sq. in/colony representing, 4.90, 3.78, 3.02 and $2.99 \%$ in Italian, Carniolan hybrid, Carniolan and Italian hybrid, respectively (Fig. 6).

The Italian race was in the first rank according to workers brood rearing activity in the four seasons with significant differences in spring and autumn. In spring, the averages were 541, 522, 429 and 359 sq. in/colony representing, 35.79, 39.80, 34.96 and 31.87\% in Italian, Carniolan, Italian hybrid and Carniolan hybrid colonies, respectively. During summer, the amounts were 357, 318, 273 and 272 sq. in/colony representing, 23.62, 25.93, 24.24 and 20.76\% in Italian, Italian hybrid, Carniolan hybrid and Carniolan colonies, respectively. There was a slight increase in autumn with average amounts of 328, 312, 300 and 289 sq. in/colony representing, 25.01, 25.41, 26.63 and 25.71\% in Carniolan, Italian hybrid, Carniolan hybrid and Italian colonies, respectively. Meanwhile, the lowest averages were recorded in winter with 225, 195, 189 and 168 sq. in/colony in Italian, Carniolan hybrid, Carniolan and Italian hybrid colonies representing, 14.88, 17.26, 
14.43 and $13.70 \%$, respectively (Figs. $7 \& 8$ ). The total averages of worker brood amounts during the whole year were 697.69, 605.38, 566 and 520.46 sq. in/colony/year in Italian, Carniolan, Italian hybrid and Carniolan hybrid colonies, respectively.

Analysis of variance showed significant differences in workers brood amount between the four races in spring and autumn. Post-hoc LSD test showed significant differences between Italian and Carniolan, between Italian and Carniolan hybrid and between Italian hybrid and Carniolan hybrid colonies in spring (Fig. 7). There were no correlation between temperature and workers brood amount in the four honeybee races. Otherwise, there were significant negative correlations between relative humidity amount of workers brood in the tested four races. The correlation coefficients were $-0.494,-0.528,-0.321$ and -0.453 and the determination coefficients were 24.37, 27.86, 10.31 and $20.51 \%$ for Italian, Italian hybrid, Carniolan, Carniolan hybrid colonies, respectively (Fig. 9). There was only a significant positive correlation between worker brood and stored pollen amounts in Italian race. The correlation coefficient was 0.510 and determination coefficient was $26.02 \%$. There were insignificant correlation between workers brood and stored pollen amounts in the other investigated three race colonies (Fig. 10).
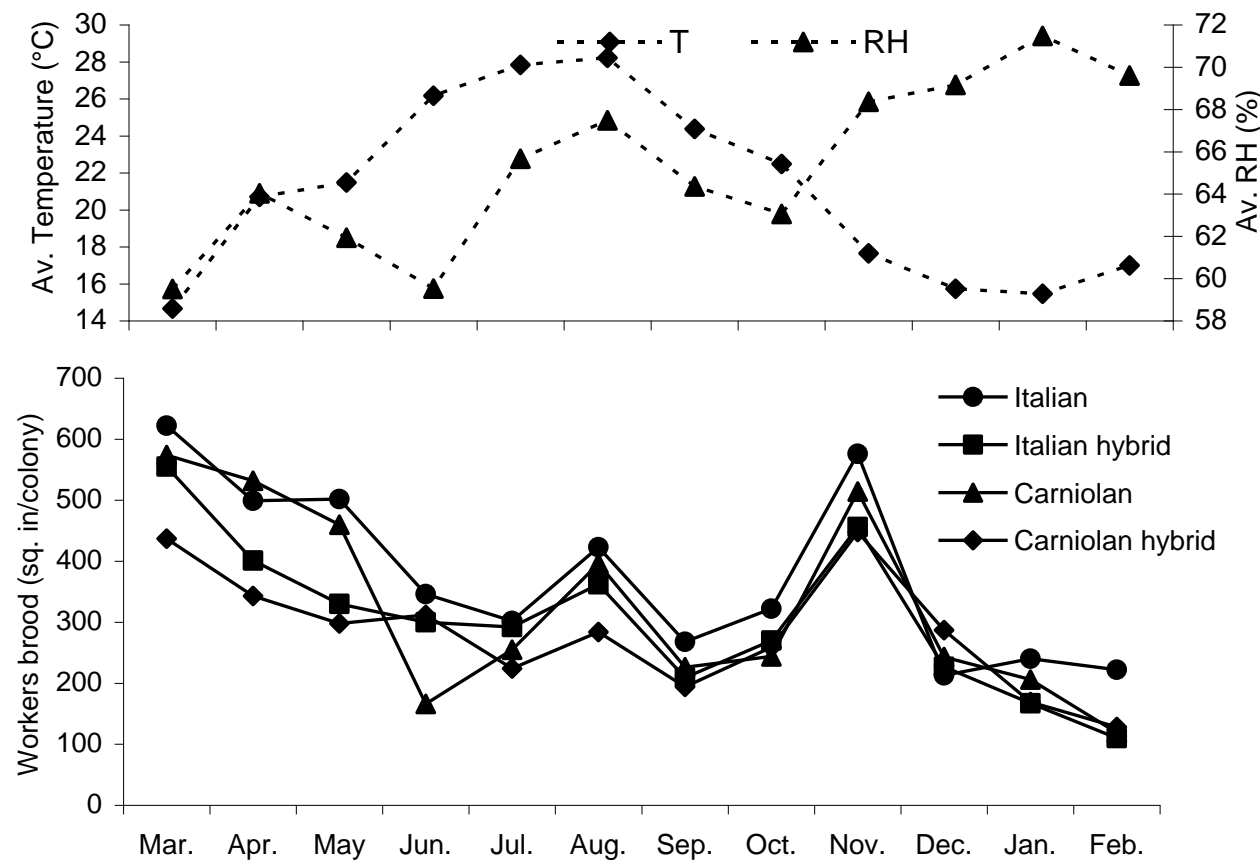

Fig. 6. Monthly averages of sealed worker brood areas reared in the honeybee race colonies under different temperatures and relative humidity conditions during a whole year.

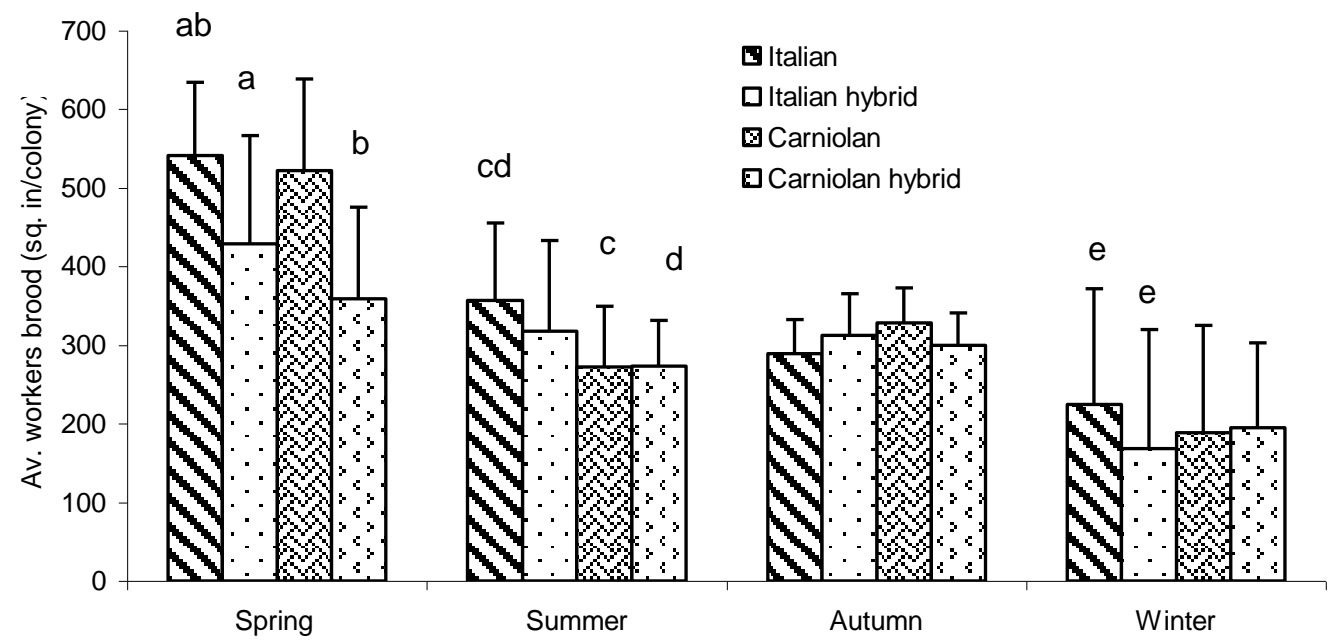

Fig. 7. Seasonal averages of sealed worker brood areas reared in the honeybee race colonies under different temperatures and relative humidity conditions during a whole year. The bars representing SD and the same letter means a significant difference. 


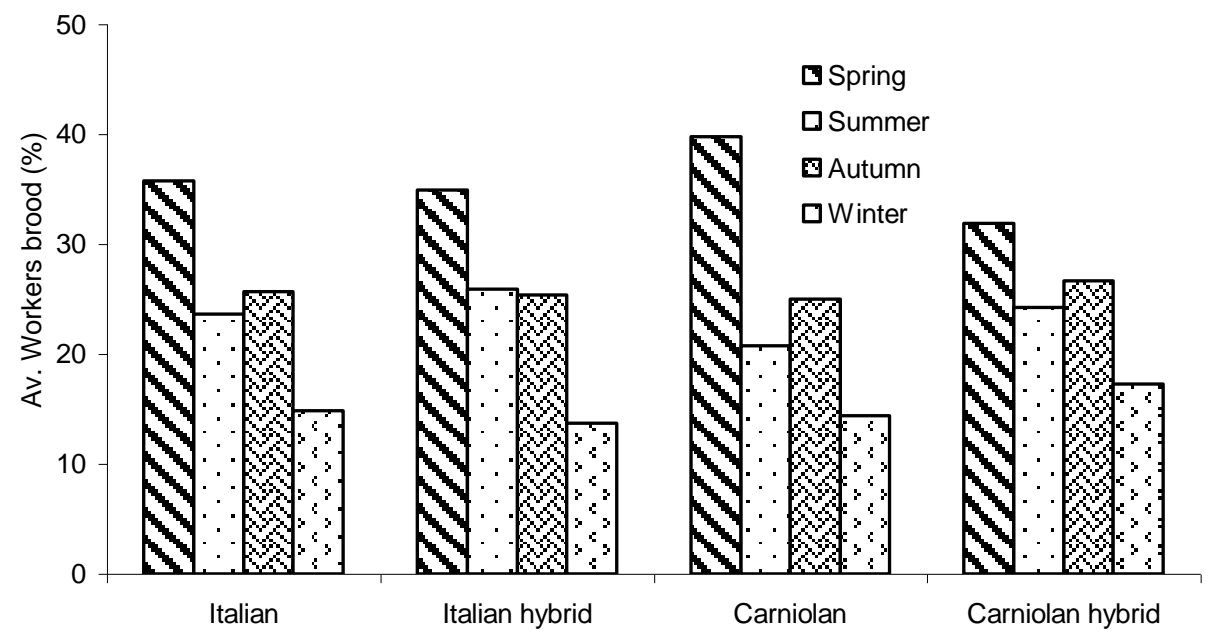

Fig. 8. Percentages of sealed worker brood areas reared in the honeybee race colonies under natural temperatures and relative humidity conditions during a whole year.

Italian

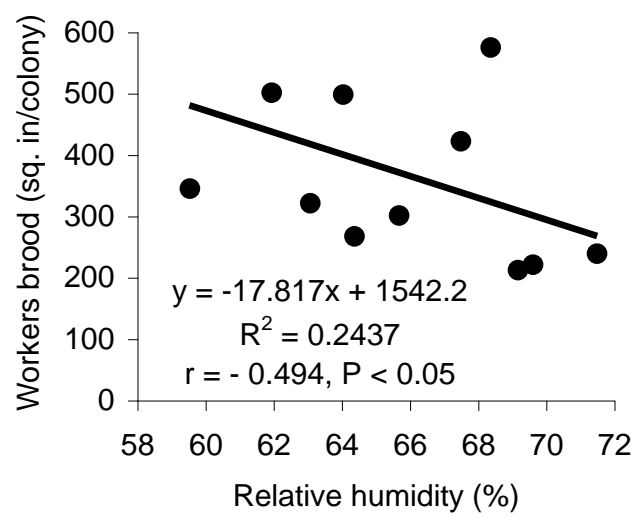

Carniolan

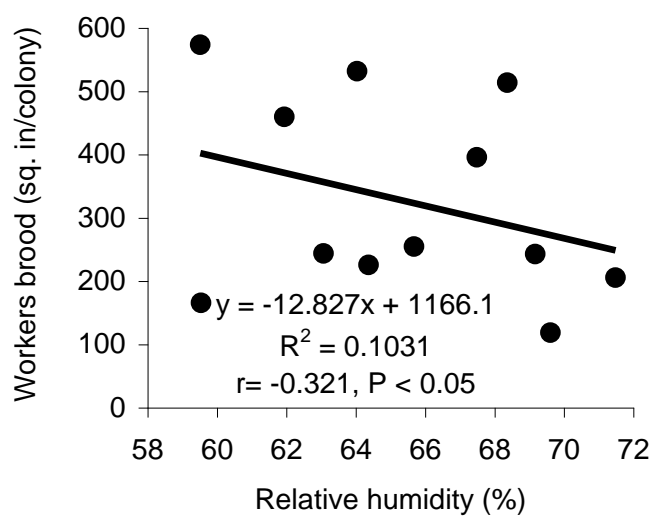

Italian hybrid

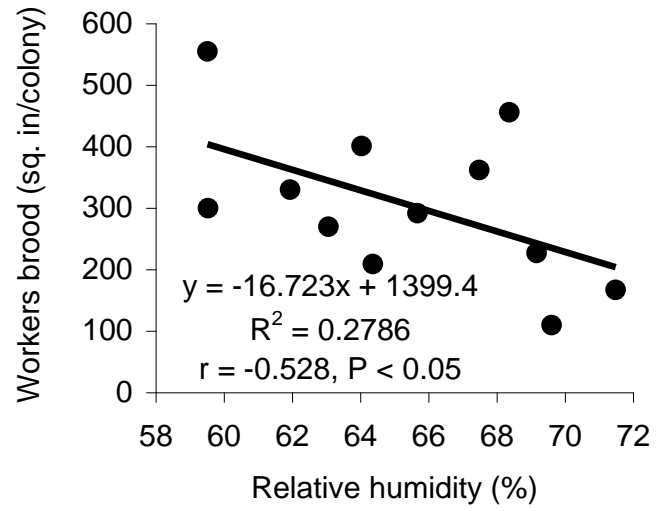

Carniolan hybrid

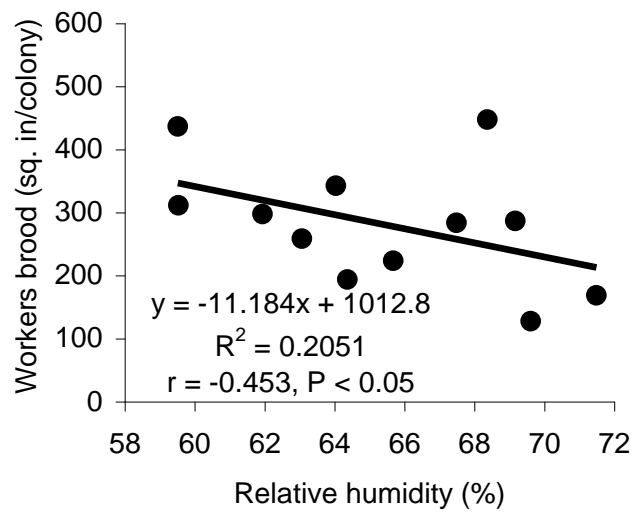

Fig. 9. Regression analysis and correlation between relative humidity and sealed worker brood areas reared in the honeybee race colonies during a whole year. $\mathrm{R}^{2} \times 100=$ determination coefficient and $\mathrm{r}=$ correlation coefficient. 


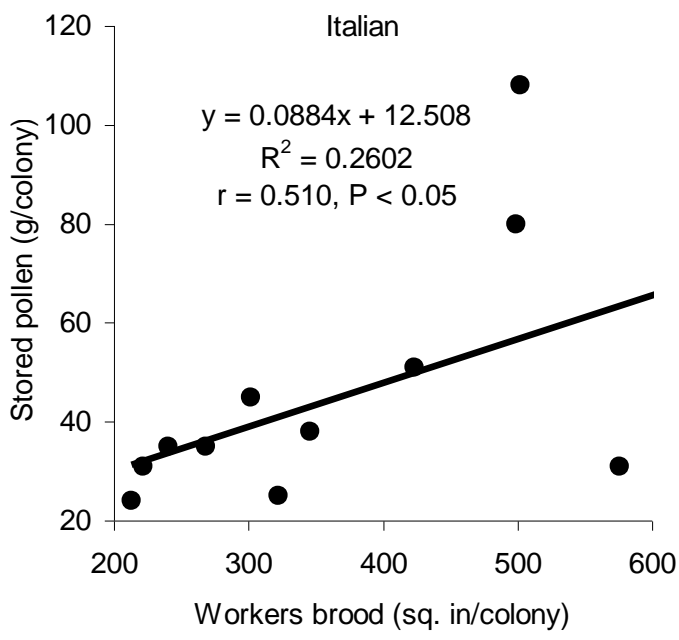

Fig. 10. Regression analysis and correlation between sealed workers brood and stored pollen amounts of the different honeybee races.

\section{Discussion}

The present results revealed that the largest amounts of stored pollen were recorded in spring and the lowest were in winter in the four evaluated honey bee races. The Italian and Italian hybrid races were more active in pollen storage activity in comparison with the Carniolan and Carniolan hybrid races with significant differences. It was observed two peaks in May (clover flowering season) and in August (maize flowering season), whereas, the lowest amounts was recorded in December. The averages of temperature ranged from 14.67 to $28.22^{\circ} \mathrm{C}$ and the averages of relative humidity ranged from 59.21 to $71.48 \%$ during the whole year. There is significant positive correlation between the temperature and pollen storage activity in Italian hybrid and Carniolan races. Also, there is significant negative correlation between relative humidity and pollen storage activity in case of Italian and Italian hybrid races.

These results are in agreement with some works revealed that pollen collection was in the highest level in March and September. The lowest activity was observed during June, November and December [25]. It was observed that honey bees can forage over a $30^{\circ} \mathrm{C}$ range of air temperature largely because they have behavioral and physiological mechanisms for regulating the temperature of their flight muscles [26]. Meanwhile, the minimum temperature needed for active foraging for European honeybees was approximately $13^{\circ} \mathrm{C}$ [27]. $\mathrm{He}$ also concluded that above $43^{\circ} \mathrm{C}$ nectar and pollen foraging were ceased but water foraging was continued. The number of pollen foragers, amount of pollen stored as beebread and brood in the colony differed significantly during different seasons [28]. Though, the total amounts of stored pollen by Apis mellifera is 4 times more than those recorded in this study by the four investigated honey bee races. This may be due to the climate and forests in Nepal in comparison with Egypt. The lowest amount of pollen was recorded in rainy season. It was found that European bees had longer foraging life than Africanized bees [29]. The native Carniolan colonies stored more pollen than the Carniolan hybrid or Egyptian bees [30]. Also, this is in concurrent with [13] who recorded that the foraging behavior in relation to five environmental parameters. It was concluded that the foraging population correlated significantly and positively with air temperature, light intensity, solar radiation and nectar-sugar concentration and negatively with relative humidity.

On the contrary of this research, it was recorded that the first Carniolan hybrid surpassed their parents in brood production and pollen gathering, followed by the pure indigenous race, then the pure Carniolan race in Sudan [31]. There were insignificant differences between the mean amounts of pollen grains collected by Italian hybrid and Carniolan hybrid bee races [21]. It was studied the activities of honeybee colonies of indigenous Apis mellifera jemenitica (AMJ) and imported Apis mellifera carnica (AMC) during the late summer and autumn in KSA [22]. In Assir, the mean maximum temperature was less than $32^{\circ} \mathrm{C}$ and the minimum was below $2^{\circ} \mathrm{C}$. Workers of the two races exhibited relatively similar forage timings throughout the period of study (AugustNovember). Although foraging activity was negatively affected by decreased temperature, AMJ was more resistant to cold than AMC.

The present findings showed that the workers brood rearing cycle in all races did not correlate with temperature and negatively correlated with relative humidity. The common features of brood rearing activity indicated that the climax occurred during spring and the lowest activity was recorded during winter for the four races. Italian bees significantly exhibited the highest brood rearing activity followed by the Carniolan bees. The Carniolan hybrid and Italian hybrid race significantly produced less workers compared with Italian race. The 
Italian colonies were more populous, while other races were less populous due to the rearing activity of worker. In the same concurrent, hybrid bees were similar to the parent generations regarding the size of the reared brood, queen fecundity and swarming [32]. The brood rearing activity in F1 hybrid honeybees, Carniolan and Buckfast, was affected to a greater extent by environmental conditions compared with genetic characteristics [33]. Also, during spring, the Italian colonies produced the highest percentage of workers followed by the Carniolan and Egyptian colonies. In brood rearing activity, hybrid races were more correlated with relative humidity [19, 34].

In contrast of this study, hybrid Sudanese bees surpassed their parents in 10 traits including brood rearing and honey and pollen production [35]. Sudanese bees exhibited better early brood rearing, pollen storing and flight activity compared with colonies of Yemeni race, followed by Carniolan bees, but Sudanese bees were more aggressive [31]. The F1 hybrid of Yemeni and Carniolan races surpassed their parents in 4 producible and 8 behavioral traits [36]. A. m. carnica presented the highest percentage of egg-hatching and sealed brood followed by A. m. ligustica, which their percentage negatively correlated with temperature [37].

In Italian bees, it was observed a positive significant correlation between workers brood rearing and pollen storage activities. This is in agreement with the findings that revealed a direct relation between both activities [25]. Also, it was found that both pollen storage and brood rearing over 4 years increased steadily in March, April and May [38]. Honey bees produced the lowest number of brood and bees in rainy season, in which starvation and nutritional deficiencies occurred due to the acute shortage of pollen before the honey flow season [28]. Also, pollen ensures the growth of colonies because it provides protein to adult bees and stimulates brood rearing [39]. It was recorded a positive significant correlation between the sealed brood area and the stored pollen amount in Carniolan and Yemeni races [22].

Because bees do not hibernate, the activity of bee colonies is significantly affected by temperature fluctuations [26, 40]. Though, in this research, non-correlation between temperature and workers brood rearing activity contradicts with some works. The fluctuation in brood may be owed to complicated internal and external factors [19, 34]. The internal factors include bee race, queen fecundity, colony size, stored food and beekeeping practices. The external factors are like temperature, humidity and nectar and pollen sources. Other important factors include supplementary feeding [41], seasons [42], intensity of worker bees, queen age and protection from diseases [43]. In other words, two factors are involved in the foraging decision making process of individual workers. Internal factors are the bee memory and the response threshold that determine the response to foraging stimuli. External factors are environmental and colony conditions, which determine the degree of exposure to stimuli associated with the decision $[44,45,46]$.

\section{Conclusion}

The research has provided a comparison between the most common four honey bee races in the Egyptian beekeeping. The paper not only focus on pollen as a principal product of the hive, but also it draws attention to the importance of beekeeping in plants and crops pollination by foraging for pollen. Nowadays, colony collapse disorder is an indicator to a severe problem threatens honey bees worldwide. Hence, the maintenance and extension of the honey bee colony become an essential and inevitable issue. This study revealed that the Italian and Italian hybrid races were the highest in pollen storage activity, while, the Italian and Carniolan races were the first in workers brood rearing activity. So, the Italian race is the most efficient among the investigated races in both activities. Unfortunately, the Italian race produces lesser amounts of honey and is less common in the Egyptian apiculture. The two parent races surpassed their hybrids, indicating that the hybridization of honey bee races are not always an advantage for beekeeping. This argues more importance and researches concerning the highly brood producing races as honey bees, indeed, are the humanity food and life.

\section{References}

[1] Morse, R. A. and Calderon, N. W. 2000. The value of honey bee pollination in the United States. Bee Cult., 128: 1-15.

[2] Thorp, R. W. 2000. The collection of pollen by bees. Plant Syst. Evol., 222: 211-223.

[3] Basim, E.; Basim, H. and Ozcan, M. 2006. Antibacterial activities of Turkish pollen and propolis extracts against plant bacterial pathogens. J. Food Eng., 77: 992-996.

[4] Almaraz-Abarca, N.; Campos, M. G. and Avila-Reyes, J. A. 2004. Variability of antioxidant activity among honey-bee collected pollen of different botanical origin. J. Sci. Technol. Am., 29: 574-578.

[5] Broadhurts, C. L. 1999. Bee products: medicine from the hive. Nutr. Sci. News, 4: 366-368.

[6] Carpes, T. 2008. Estudo das Caracteristicas Fisico-Quimicas e Biologicas do Polen Apicola de Apis mellifera da regiao Sul do Brasil. Tese apresentada ao Programa de Pos-Graduacao em Tecnologia de Alimentos, Sector de Tecnologia da Universidade Federal do Paraná.

[7] LeBlanc, B. W.; Davis, O. K.; Boue, S.; DeLucca, A. and Deeby, T. 2009. Antioxidant activity of Sonoran Desert bee pollen. Food Chem., 115: 1299-1305.

[8] Morais, M.; Moreira, L.; Feás, X. and Estevinho, L. M. 2011. Honeybee-collected pollen from five Portuguese Natural Parks: Palynological origin, phenolic content, antioxidant properties and antimicrobial activity. Food Chem. Toxicol., 49: 1096-1101.

[9] Winston, M. L. 1987. The biology of the honey bee. Harvard University Press, Cambridge, MA, USA.

[10] Lee, P. C. and Winston, M. L. 1987. Effects of reproductive timing and colony size on survival, offspring colony size and drone production in the honey bee (Apis mellifera L.). Ecol. Entomol., 12: 187-195. 
[11] Hrassnigg, N. and Crailsheim, K. 1998. Adaptation of hypopharyngeal gland development to the brood status of honeybee (Apis mellifera L.) colonies. J. Insect Physiol., 44: 929-939.

[12] Ali, M. A. M. 2007. Effect of supplemental feeding on brood production and population development of honey bee (Apis mellifera jementica). Minufia J. Agric. Res., 32(3): 915-932.

[13] Abrol, D. P., 2010. Foraging behavior of Apis florae F., an important pollinator of Allium cepa L. J. Apicult. Res., 49(4): $318-325$.

[14] Abrol, D. P. 2006. Diversity of pollinating insects visiting litchi flowers (Litchi chinensis Sonn.) and path analysis of environmental factors influencing foraging behavior of four honeybee species. J. Apicult. Res., 45: 180-187.

[15] Ellis, M. B.; Nicolson, S. W.; Crewe, R. M. and Dietemann, V. 2008. Hygropreference and brood care in the honeybee (Apis mellifera). J. Insect Physiol., 54: 1516-1521.

[16] Sheppard, W. S. and Meixner, M. D. 2003. Apis mellifera pomonella, a new honey bee subspecies from Central Asia. Apidologie, 34: 367-375.

[17] Page, R. E. and Laidlaw, H. 1980. Egyptian beekeeping. Amer. Bee J., 120(11): 776-779.

[18] Rock, H. J. 1977. Variations in different strains of bees. Glean. Bee Cult., 105(7): 312-313.

[19] Cobey, S. 1992. The Carniolans Apis mellifera carnica. Amer. Bee J., 132(4): 246-248.

[20] Ali, M. A. M. 2011. Comparative study for evaluating two honey bee races, Apis mellifera jementica (indigenous race) and Apis mellifera carnica (Carniolan race) in brood production, population development and foraging activity under the environmental conditions of the central region of the Kingdom of Saudi Arabia. Ann. Agr. Sci., 56(2): 127-34.

[21] EI-Hefny, A.; Usef, A. D. M.; Shehat, I. A. A. and Ahmed, S. N. 2012. Comparative studies between Carniolan and Italian hybrid honey bee activities in Nasr City, Cairo. J. Plant Prot. Path., Mansoura Univ., 3(1):71-79.

[22] Alqarni, A. S.; Balhareth, H. M. and Owayss, A. A. 2014. Performance evaluation of indigenous and exotic honey bee (Apis mellifera L.) races in Assir region, southwestern Saudi Arabia. Saudi J. Biol. Sci., 21: 256-264.

[23] Al-Tikrity, W. S.; Hillmann, R. C.; Benton, A. W. and Clarke, W. W. 1971. A new instrument for brood measurement in a honey bee colony. Amer. Bee J., 111(4): 143-145.

[24] Taha, A. A. 2006. Comparative studies on some secondary products in different races. Ph. D., Econ. Entomol. Dept., Fac. Agric., Mansoura Univ., Mansoura, Egypt.

[25] Hussein, M. H. 1981. Pollen-gathering activity of honeybee workers in Assuit Governorate. Proceeding, $4^{\text {th }}$ Arab Pesticide Conf., Tanta Univ., Special Vol.: 377- 385.

[26] Heinrich, B. 1996. How the honey bee regulates its body temperature. Bee World, 77(3): 130-137.

[27] Gary, N. E. 1999. Activities and behavior of honey bees. In: Graham Joe, M. (Ed.), The Hive and The Honey Bee. Dadant \& Sons, Hamilton, Illinois, pp. 269-372.

[28] Neupane, K. R. and Thapa, R. B. 2005. Pollen collection and brood production by honeybees (Apis mellifera L.) under Chitwan condition of Nepal. J. Inst. Agric. Anim. Sci., 26: 143-148.

[29] Guzmán-Becerra, F.; Guzmán-Novoa, E.; Correa-Benítez, A. and Zozaya-Rubio, A. 2005. Length of life, age at first foraging and foraging life of Africanized and European honey bee (Apis mellifera) workers during conditions of resource abundance. J. Apicult. Res., 44(4): 151-156.

[30] Amro, A. M. A. 2009. Seasonal variations in some characters of two races of honeybee and their hybrid in Assiut Region. M. Sc. Thesis, Fac. Agric. Assiut Univ., Egypt, p. 243.

[31] Nagi Siham, K. A. 1990. Studies on Sudanese and Carniolan honeybees. Ph. D. Thesis. Fac. Agric. Univ., Khartoum, Sudan, pp. 5378.

[32] Subbotin Y. A. 1969. Inheritance of economically useful characteristics in bees bred from crosses between different races. Materials of Jubilee Science conference of Moldavian Research Institute for Animal Breeding and veterinary science, pp. 58-60.

[33] Ruttner F. and Ruttner H. 1976. Late summer brood of colonies of different races and their dependence on environmental conditions. Allge. Deutche Imkerze., 10(11): 417-421.

[34] Yakoub, W. A. 1998. Comparative studies on some honeybee races. M. Sc. Thesis, Fac. Agric., Alex. Univ., 122-126 pp.

[35] El-Sarrag, M. S. A. 1977. Morphometrical and biological studies on Sudanese Honeybees, Apis mellifera (Hymenoptera, Apidae). Ph. D. Thesis, Fac. Agric., Cairo Univ., Cairo, Egypt.

[36] El-Sarrag, M. S. A. 1993. Some factors affecting brood rearing activity honeybee colonies in the Central Region of Saudi Arabia. J. King Saud Univ. Agric. Sci., 5(1): 97-108.

[37] Al-Ghamdi, A. 2005. Comparative study between subspecies of Apis mellifera for egg hatching and sealed brood percentage, brood nest temperature and relative humidity. Pakistan J. Biol. Sci., 8(4): 626-630.

[38] El-Sherif, M. E.; Mazeed, M. M. and Abou El-Enain, H. T. 1994. Effect of pollen absence in honeybee colonies on drone and worker brood rearing activity. $5^{\text {th }}$ Conf. Agric. Dev. Res., Fac. Agric., Ain Shams Univ., Cairo, Egypt.

[39] DeGrandi-Hoffman, G.; Wardell, G.; Ahumada-Secura, F.; Rinderer, T. E.; Danka, R. and Pettis, J. 2008. Comparisons of pollen substitute diets for honeybees: consumption rates by colonies and effects on brood and adult populations. J. Apicult. Res., 47: 265270.

[40] Graham, J. M. 1992. The Hive And The Honey Bee. Dadant \& Sons, Inc., Hamilton, IL. 1324 pp.

[41] Free, J. B. and Booth, Y. S. 1961. The effect of feeding sugar to honeybee colonies. J. Agric. Sci., 57(2): 147-152.

[42] Free, J. B. and Racey, P. A. 1968. The effect of the size of bee colonies on food consumption, brood rearing and the longevity of the bees during winter. Exp. Appl. Entomol., 11: 241-249.

[43] Abdel-Latif, M. A. and Aboul-Naga, A. M. 1975. Studies on queen activity of egg laying. $2^{\text {nd }}$ Scientific Conf. Baghdad, Iraq

[44] Seeley, T. D. 1995. The Wisdom of the Hive, Harvard University Press, Cambridge, MA, USA.

[45] Biesmeijer, J. C.; van Nieuwstadt, M. G. L.; Lukács, S. and Sommeijer, M. J. 1998. The role of internal and external information in foraging decisions of Melipona workers (Hymenoptera: Meliponinae). Behav. Ecol. Sociobiol., 42(2): 107-116.

[46] Biesmeijer, J. C. and de Vries, H. 2001. Exploration and exploitation of food sources by social insect colonies: a revision of the scout-recruit concept. Behav. Ecol. Sociobiol., 49(2-3): 89-99. 